\title{
Measuring Adolescents' Perceptions of Parenting Style During Childhood: Psychometric Properties of the Parenting Styles and Dimensions Questionnaire
}

\author{
Semira Tagliabue ${ }^{1}$ \\ Università Cattolica del Sacro Cuore di Brescia \\ Maria Giulia Olivari \\ Università Cattolica del Sacro Cuore di Milano \\ Dario Bacchini \\ Gaetana Affuso \\ Sevonda Università degli Studi di Napoli \\ Emanuela Confalonieri \\ Università Cattolica del Sacro Cuore di Milano
}

\begin{abstract}
The paper analyzes the psychometric properties of the G1 version of the Parenting Styles and Dimensions Questionnaire, a self-report instrument designed to investigate how adolescents or adults were parented during childhood. The sample included 1451 Italian adolescents in high school. Three studies tested the scale's structure, invariance, and convergent validity. The first found slightly acceptable fit indexes for a 40-item scale measuring three factors (authoritative, authoritarian, and permissive styles); the factors presented good reliability $\left(\rho_{\mathrm{c}} \cdot 62-.96\right)$. Multigroup confirmative analyses found factor loadings invariant in the father version, whereas 12 items resulted not invariant in the mother version (second study). Good convergent validity was found with the Parental Bonding Index and the Parental Monitoring Scale (third study). Discussion of results is provided within the parenting styles literature.
\end{abstract}

Keywords: parenting styles, adolescents, psychometric properties, family

\section{Medindo a Percepção dos Estilos Parentais de Adolescentes Durante a Infância: As Propriedades Psicométricas do Estilo Parental e do Questionário de Dimensões}

\begin{abstract}
RESUMO - O presente trabalho analisa as propriedades psicométricas da versão G1 do Parenting Styles and Dimensions Questionnaire (Questionário de Estilo e Dimensões de Parentalidade), um instrumento de autorrelato projetado para investigar retrospectivamente como adolescentes ou adultos foram criados durante a infância. A amostra incluiu 1451 adolescentes italianos cursando o ensino médio. Três estudos foram apresentados, nos quais a estrutura da escala, sua invariância, e sua validade convergente são testadas. O primeiro estudo encontrou índices ligeiramente aceitáveis para uma escala de 40 itens medindo três fatores (estilos autoritativo, autoritário, permissivo); os fatores apresentaram uma boa confiabilidade $\left(\rho_{\text {crange }} .62-\right.$ .96). Análises confirmativas multigrupo descobriram que as cargas de fatores foram invariantes, na versão do pai, enquanto que doze itens resultaram não invariantes na versão da mãe. Uma boa validade convergente foi encontrada com Parental Bonding Index, e Parental Monitoring Scale no terceiro estudo. A discussão dos resultados é provida na literatura de estilos parentais.
\end{abstract}

Palavras-chave: estilos parentais, adolescentes, propriedades psicométricas, família

Socio-psychological research on family relationships has emphasized parents' role in influencing children and adolescents' emotional and social development. Parenting style during childhood has short-term and long-term effects on parent-child relationship (Darling \& Steinberg, 1993). According to Baumrind $(1971,1989)$ and Maccoby and Martin (1983), parenting styles arise from the crossing of two different dimensions: demandingness and responsiveness. Demandingness is "the claims parents make on children to become integrated into the family whole, by their maturity demands, supervision, disciplinary efforts, and willingness to confront the child who disobeys" (Baumrind, 1991, pp. 61-62). Responsiveness is "the extent to which parents intentionally foster individuality, self-regulation, and selfassertion by being attuned, supportive, and acquiescent to

1 Endereço para correspondência: Department of Psychology, Università Cattolica of Brescia. Via Trieste, 17, 25121, Brescia, Italy.E-mail: semira.tagliabue@unicatt.it children's special needs and demands" (Baumrind, 1991, p. 62).

Several studies classify parenting into three styles (e.g., Baumrind, 1971; Darling \& Steinberg, 1993). Authoritarian parents are highly demanding and directive, but not responsive. Their child-rearing pattern combines high control and strict and coercive discipline with aggressive behaviors. These parents expect orders to be obeyed without explanation and offer a low level of trust and engagement toward the child. Authoritative parents are demanding and responsive. Their discipline is controlling but not restrictive, oriented to the child's involvement in the family's life. They offer trust, support, control, and open communication toward the children. Permissive parents are highly responsive, but not demanding. Their child-rearing pattern combines nondemanding behavior, low parental control, and low levels of disciplinary action. They offer warm acceptance and childcentered orientation. 
A recent review (Olivari, Tagliabue, \& Confalonieri, 2013), found authoritative parenting style positively associated with adaptive behaviors and psychological adjustment and negatively associated with maladaptive behaviors and psychological maladjustment. Other reviews agreed (Kawabata, Alink, Tseng, van IJzendoorn, \& Crick, 2011; Newman, Harrison, Dashiff, \& Davies, 2008; Piko \& Balázs, 2012), suggesting the protective role authoritative parenting plays in adolescence.

The increasing investigation of parenting styles and their links with developmental outcomes in childhood and adolescence has been accompanied by a rise in selfreport instruments measuring parenting styles (Perlmutter, Touliatos, \& Holden, 2001; Touliatos, Perlmutter, Strauss, \& Holden, 2001; Weber, Salvador, \& Brandenburg, 2006, 2009). Among them, Robinson, Mandleco, Olsen, and Hart (1995) created a widely used instrument, the Parenting Styles and Dimensions Questionnaire (PSDQ). International and cross-cultural studies used this instrument increasingly in the last three years, as showed in Olivari and colleagues (2013).

In 2000, Chipman, Olsen, Klein, Hart, and Robinson proposed a new adaptation of PSDQ and investigated how the young adults were parented by their mothers and fathers during their childhood. In 2001, Robinson, Mandleco, Olsen, and Hart presented the PSDQ scale and the G1 version in the Handbook of Family Measurement Technique. This scale was designed to investigate how adolescents or adults were parented during childhood and was used in some recent studies (Confalonieri et al., 2010; O'Brien, 2010; Tagliabue et al., submitted), even though there is not to date a proper psychometric analysis of the PSDQ. The aim of the present paper is to test its psychometric properties in the Italian context, working on the full instrument and assessing its reliability through CFA. The samples of the previous studies were quite small, whereas the present study uses a large sample. It tests two versions of the scale: one relating to fathers' parenting styles and one relating to mothers' parenting styles.

The descriptive comparison of the two versions will determine if the measurement of parenting style is similar or different for the two parents. Moreover, because previous studies underlined differences in how parenting is done in the North and South of Italy, due to the positive correlation between authoritarian and permissive style in the South (Confalonieri et al., 2010), multi-group analyses will investigate the measurement invariance of the scale in two sub-samples representing the north and south of Italy. There are socio-cultural differences between the two regions. The North region has more single-child families, the South region more families with multiple children. The North also has a growing number of single-parent families more than the South (ISTAT, 2006). Twice as many women in the North are employed as in the South. Therefore, in the North both parents are often employed, while in the South the mother is more often unemployed and stays at home spending more time with her children (ISTAT, 2013). Convergent validity will be tested through correlations with the Parental Bonding Index (PBI, Parker, Tupling, \& Brown, 1979) and the Parental Monitoring Scale (Stattin \& Kerr, 2000).

\section{Method}

\section{Participants}

Participants were 1451 adolescents who filled in a questionnaire about the parenting styles of their parents when the participants were children. We recruited school samples ad hoc taking into account schools' geographical position (North and South of Italy) and recruiting adolescents that agreed to participate in the research.

Data from seven adolescents who answered items regarding their mother and data from 17 adolescents who answered items regarding their father were excluded from the analyses because of missing data regarding the other parent. Data from 1430 adolescents (49.8\% males) who answered about both parents constitutes the valid data of the present study. EM analysis computed missing data on single items. Adolescent age ranged from 13 to 19 years old $\left(\mathrm{M}_{\text {age }}=16.60\right.$ years, $\left.\mathrm{SD}_{\text {age }}=1.5\right)$. Specifically, $53.8 \%$ of the participants were from northern Italy and $46.2 \%$ from southern Italy. Respectively, $41.0 \%, 42.8 \%$, and $16.2 \%$ of the adolescents reported that their fathers had a low (junior high or less), medium (high school diploma), or high (university degree) educational level. Adolescents reported that their mothers had a low (43.3\%), medium (44.6\%), and high (15.1\%) educational level respectively.

\section{Procedure}

Participants completed a form containing sociodemographic characteristics (i.e., gender and age) and three self-report instruments about the parent-child relationship they experienced. The questionnaire was approved by Catholic University of the Sacred Heart of Milan Ethics Committee and by Second University of Naples Ethics Committee. The headmaster and class teachers permitted the research study and the parents gave written consent for their children.

\section{Instruments}

Socio-demographic characteristics. Participants were given a socio-demographic questionnaire that ascertained information about their parents' gender, age, nationality, schools, and educational qualification.

Parenting Styles and Dimensions Questionnaire. Participants responded to the G1 version of the PSDQ developed by Robinson et al. (2001), which assesses adolescents' perceptions of their parents' parenting styles during childhood. The questionnaire measures three main parenting styles: authoritative, authoritarian, and permissive. Participants rated 62 items reflecting on each of their parents' behavior, using a 5-point scale from 1 (never) to 5 (always). The instrument was comprised of 62 items divided into three parts: 27 questions belonging to the authoritative style, 20 questions to the authoritarian style, and 15 questions to the permissive style. The authors of the instrument subjected 
each set of items into principal axis factor analysis (PAF), extracting four factors from the authoritative style (warmth/ involvement with 11 items, reasoning/induction with seven items, democratic participation with five items, and good nature/easy going with four items), four factors from the authoritarian style (verbal hostility with four items, corporal punishment with six items, non-reasoning/punitive strategies with six items; and directiveness with four items), and three factors from the permissive style (lack of follow-through with six items; ignoring misbehavior with four items, and self-confidence with five items).

Two versions were used: one to evaluate the father's parenting style and another one to appraise the mother's parenting style. Two experienced Italian psychologists, fluent in English, translated the PSDQ. A native English-speaking expert translated the scale back to English. Researchers compared the original to the Italian translation and finalized the Italian version.

Parental Bonding Index. The PBI by Parker et al. (1979) is a 25-item self-report questionnaire, validated for Italy by Scinto, Marinangelia, Kalyvoka, Daneluzzo, and Rossi (1999), ranging from 1 (very unlikely) to 4 (very likely), describing parental attitudes and styles as perceived by the adolescent. Two scores are obtained for each parent separately: a care score (e.g., "Spoke to me in a warm and friendly voice"; 12 items; $\alpha_{\text {mo }}=.87 ; \alpha_{\mathrm{fa}}=.89$ ) and an overprotection score (e.g., "Tried to control everything I did"; 13 items; $\left.\alpha \mathrm{mo}=.76 ; \alpha_{\mathrm{fa}}=.74\right)$.

Parental Monitoring Scale. The Parental Monitoring Scale by Stattin and Kerr (2000), validated for Italy by Miranda, Bacchini and Affuso (2012), is a 25-item selfreport questionnaire, ranging from 1 (no or almost never) to 5 (very often or always). The questionnaire measures four main dimensions: 1) 9 items on parental knowledge (e.g., "Do your parents know what you do in your spare time?"; $\alpha$ $=.85$ ), 2) five items on youth disclosure (e.g., "Do you hide a lot from your parents about what you do during the day?"; $\alpha=.75), 3$ ) six items on parental control (e.g., "Do you need your parents' permission before going out in the evening?"; $\alpha$ $=.85$ ), and 4) five items on parental solicitation (e.g., "How often do your parents ask you about things that happened during school?"; $\alpha=.73$ ).

\section{Data Analyses}

After verifying the normal distribution of the items, we split the data into three sub-samples. We used the first sample to study the structure of the scale for mothers and fathers, the second to test the measurement invariance, and the third to verify convergent validity.

Confirmatory factor analyses (CFA) using ML estimation method and AMOS software tested the scale's structure (Arbuckle \& Wottke, 2003). Goodness-of-fit indexes were examined through Chi square test, RMSEA, and CFI. Models with acceptable fit presented non significant $\mathrm{Chi}$ square value, RMSEA $<.08$ and CFI $>.90$ (Bentler, 1990), whereas models with optimum fit presented non significant $C$ hi square value, RMSEA $<.05$ and CFI $>.95$ (Hu \& Bentler, 1999). However, because Chi square test is sensitive to sample size, models with a large sample could only be evaluated with RMSEA and CFI (Byrne, 2010). The following formula computed reliability in the CFA context: $\rho_{\mathrm{c}}=\left(\Sigma \lambda_{1}\right)^{2} /\left[\left(\Sigma \lambda_{1}\right)^{2}+\left(\Sigma \varepsilon_{1}\right)\right]$, where $\rho_{\mathrm{c}}$ is the reliability, $\lambda$ is the factor loadings, and $\varepsilon$ represents the error variance (Bagozzi, 1994, p. 324).

Multigroup confirmative analyses tested measurement invariance in the two geographically divided sub-samples. Two invariances were tested: regression weights and covariances among the three latent factors. The significance of the differences between the unconstrained model and the regression weights and covariances in the invariant models were tested through the $\Delta \chi^{2}$. Finally, convergent validity was tested through correlations between parenting styles, Parental Bonding Index, and Parental Monitoring Scale.

\section{Results}

\section{Descriptive Analyses}

The sample was split into three sub-samples: the first included 473 adolescents, the second 478, and the third 479 . The three sub-samples showed no significant differences in age $\left(p>.05 ; F_{(2,1047)}=1.17\right)$, gender $\left(p>.05 ; \chi_{(2)}^{2}=2.14\right)$, or $\operatorname{city}\left(p>.05 \chi_{(2)}^{2}=5.48\right)$.

\section{First Study}

In the first subsample, half (54.5\%) of 473 subjects $(49.5 \%$ males; Mage $=16.51$ years, SDage $=1.49)$ were from north Italy while the other half $(45.5 \%)$ from the south. Each answered about both parents. We conducted descriptive analyses on the items, finding and excluding six non-normal (skewness and kurtosis $>1.5$ ) items from the following analyses: $4,15,30,36,45$, and 49 .

Separate confirmative analyses concerned mother-related and father-related answers. Because the aim was a valid, reliable instrument for both versions, we conducted a step-bystep comparison of the two. The first model tested the threefactor scale: 1) 27 items measuring the authoritative style factor, 2) 20 items measuring the authoritarian style factor, and 3) nine items measuring the permissive style factor. We correlated the three factors. Table 1 presents the fit indexes of the CFA models tested. In both models, a chi-square proved to be significant, and fit indexes were not acceptable (See Table 1). In both versions, items 16 (authoritative style factor) and 19 and 23 (authoritarian style factor) did not significantly saturate the factors.

We tested a second model without items 16, 19, and 23. In both versions, chi-square was significant and fit indexes were unacceptable (See Table 1).

All the items significantly saturated the latent factors with the exception of item 52 in the fathers' version. However, several items did not saturate at more than .40. These items were similar in the two versions. For the authoritative style factor, items 3,5 , and 60 , in both versions, and item 62 , in the mothers' version, did not highly saturate the factor. 
Table 1. Fit Indexes for CFA Models Tested on The First Sample (Father's and Mother's Versions)

\begin{tabular}{|c|c|c|c|c|}
\hline Model & $\chi^{2}(\mathrm{p})$ & Df & RMSEA & CFI \\
\hline Three-factor model (56 items) & $\begin{array}{l}4194.98 * * * / \\
\text { 3931.36*** }\end{array}$ & $1481 / 1481$ & $\begin{array}{c}.06 \\
(.060-.065) \\
\mathbf{. 0 6} \\
(.057-.061)\end{array}$ & $\begin{array}{l}.70 \\
.70\end{array}$ \\
\hline Three-factor model (53 items) & $\begin{array}{l}3621.86 * * * / \\
\mathbf{3 4 5 6 . 1 9} * * *\end{array}$ & $1322 / 1322$ & $\begin{array}{c}.06 \\
(.058-.063) \\
\mathbf{. 0 6} \\
(.056-.061)\end{array}$ & $\begin{array}{l}.73 \\
.73\end{array}$ \\
\hline Three-factor model (40 items) & $\begin{array}{c}2030.66 * * * / \\
\mathbf{1 8 6 7 . 8 8} * * *\end{array}$ & $737 / 737$ & $\begin{array}{c}.06 \\
(.058-.064) \\
\mathbf{. 0 6} \\
(\mathbf{. 0 5 4}-.060)\end{array}$ & $\begin{array}{l}.82 \\
.83\end{array}$ \\
\hline
\end{tabular}

Note. Bold numbers indicate the findings of the mother's version

$* * * p<0.001$

Table 2. Multigroup Models

\begin{tabular}{|c|c|c|c|c|c|}
\hline Model & $\chi 2(p)$ & Df & RMSEA & CFI & $\Delta \chi^{2}(\Delta \mathrm{Df})$ \\
\hline \multicolumn{6}{|l|}{ Father's version } \\
\hline Unconstrained-model A & $3250.37 * * *$ & 1474 & $\begin{array}{c}.05 \\
(.048-.053)\end{array}$ & .79 & \\
\hline $\begin{array}{l}\text { Invariant factor loadings- } \\
\text { model B }\end{array}$ & $3302.03 * * *$ & 1511 & $\begin{array}{c}.05 \\
(.048-.052)\end{array}$ & .79 & $\begin{array}{l}51.66 \\
(37)\end{array}$ \\
\hline Invariant covariances - model C & $3318.90 * * *$ & 1514 & $\begin{array}{c}.05 \\
(.048-.052)\end{array}$ & .79 & $\begin{array}{l}68.52^{*} \\
(40)\end{array}$ \\
\hline \multicolumn{6}{|l|}{ Mother's version } \\
\hline Unconstrained- model A & $3149.90 * * *$ & 1474 & $\begin{array}{c}.05 \\
(.047-.051)\end{array}$ & .79 & \\
\hline $\begin{array}{l}\text { Invariant factor loadings- } \\
\text { model B }\end{array}$ & $3228.04 * * *$ & 1511 & $\begin{array}{c}.05 \\
(.047-.051)\end{array}$ & .78 & $\begin{array}{c}78.11 * * \\
(37) ; \mathrm{p}<.01\end{array}$ \\
\hline $\begin{array}{l}\text { Invariant factor loadings } \\
\text { (12 items' factor loadings } \\
\text { unconstrained) - model C }\end{array}$ & $3175.82 * * *$ & 1499 & $\begin{array}{c}.05 \\
(.046-.051)\end{array}$ & .79 & $\begin{array}{c}25.89 \\
(25)\end{array}$ \\
\hline $\begin{array}{c}\text { Invariant covariances - model } \\
\mathrm{D} \text { (model } \mathrm{C}+\text { invariant } \\
\text { covariances among factors) }\end{array}$ & $3189.20 * * *$ & 1502 & $\begin{array}{c}.05 \\
(.046-.051)\end{array}$ & .79 & $\begin{array}{l}39.27 \\
(28)\end{array}$ \\
\hline
\end{tabular}

$* p<0.05 ; * * p<0.01 ; * * * 00.001$

For the authoritarian style factor, items 17, 40, 47, 50, and 59 did not highly saturate the factor in either version; and for the permissive style factor, items 8, 11, 24, 38, and 52 did not highly saturate in either versions, nor did item 41 , in the mothers' version.

We tested a third model without items that did not highly saturate the factors in at least one version (items 3, 5, 8, 11, $17,24,38,40,47,50,52,59$, and 60). The model fit improved
(See Table 1) although the CFI remained lower than .90 and most of the items highly saturated the factors, with the exception of item 41 in the fathers' version and items 13, 41, and 62 in the mothers' version. Because the fit indexes were slightly acceptable and because only four items measured the permissive style factor, we decided to keep this 40-item version (See Appendix).

Reliability, computed in the CFA context using the $\rho c$, showed good values for all styles: authoritative ( $\rho c$ fathers' 
and mothers' versions $=.96)$; authoritarian ( $\rho c$ fathers' version $=.95 ; \rho c$ mothers' version $=.94)$; and permissive $(\rho \mathrm{c}$ fathers' version $=.63 ; \rho c$ mothers' version $=.62$ ).

\section{Second Study}

The second sub-sample of adolescents was a confirmatory, which we performed multigroup analyses: 273 came from the North and 205 from the South $\left(52.3 \%\right.$ males; $M_{\text {age }}=16.66$ years, $\left.\mathrm{SD}_{\text {age }}=1.53\right)$. Each subject answered questions about both parents. A different multigroup analysis concerned each version of the scale. In the fathers' version (Model A-See Table 2), the unconstrained model presented an acceptable fit, comparable with that found for the first sample. The $\Delta \chi^{2}$ between the unconstrained model and the model in which all factor loadings were constrained to be equal in the two sub-samples was not significant (Model B - See Table 2), showing the invariance of factor loadings in the two subsamples.

The model, with factor loadings and covariances among factors constrained to be invariant in the two sub-samples, differed significantly from the unconstrained model (Model $\mathrm{C}$ - See Table 2). The inspection of covariances among factors showed the covariance between authoritative and authoritarian factors higher in the North $(r=-.56, p<$ $.05)$ than in the South $(r=-.34, p<.05)$. The covariance between authoritative and permissive factors was not significant in both sub-samples, whereas the covariance between authoritarian and permissive factors was higher in the southern sample $(\mathrm{r}=.72, p<.05)$ than in the northern one $(r=.38, p<.05)$. Thus, the covariances were different in the two sub-samples, with the exception of the one between authoritative and permissive factors, which is, however, not significant.

In the mothers' version (Model A-See Table 2), the unconstrained model presented an acceptable fit, comparable with that found on the first sub-sample. The $\Delta \chi 2$ between the unconstrained and constrained models yielded significant results (Model B-See Table 2). The inspection of factor loadings in the two sub-samples highlighted the larger difference in the estimates of the factor loadings of the following items: items 1, 9, 12, 29, 53, and 62 (higher factor loading for the North) and item 31 (higher factor loading for the South) in the authoritative factor; items 2, 6, 13, and 43 (higher factor loading for the North) in the authoritarian factor; and item 41 (higher factor loading for the South) in the permissive factor. When the factor loadings of those 12 items were unconstrained, invariant factor loadings models, with and without constrained covariances, did not differ from the unconstrained model (Models CD-See Table 2), showing the invariance of correlations between factors. In particular, the correlation between authoritative and authoritarian factors was $r=-.62$ (North) and $r=-.54$ (South) $(p<.05)$, the covariance between authoritative and permissive was $r=$ -.14 (North) and $\mathrm{r}=-.16$ (South) $(\mathrm{p}<.05)$, and the covariance between authoritarian and permissive was $r=.54$ (North) and $\mathrm{r}=.65$ (South) $(p<.05)$.

\section{Third Study}

We analyzed the third sub-sample to compute convergent validity. We found significant $(p<.05)$ and high correlations between authoritative parenting style and parental knowledge, youth disclosure, and parental solicitation scales $\left(r_{\text {range }}\right.$ from .39 to .51), whereas correlations among authoritarian and parental knowledge, youth disclosure, and parental solicitation were low, albeit significant (See Table 3). We found positive, significant, and high correlations between authoritative parenting style and parental care $\left(r_{\text {range }}\right.$ from .68 to .75), significant but negative correlations between authoritarian style and parental care ( $r_{\text {range }}$ from -.46 to -.48), and positive correlations between authoritarian style and parental overprotection ( $r_{\text {range }}$ from .30 to .34 ). Permissive style is only slightly correlated with all other constructs $\left(r_{\text {range }}\right.$ from -.27 to .16$)$.

\section{Discussion}

The present paper psychometrically evaluated the Parenting Styles and Dimensions Questionnaire. We performed CFA, yielding a psychometrically slightly acceptable 40-item scale, for both the fathers' and the mothers' version. Regarding the 22 items excluded, it should be noted that six to 15 items of the permissive dimensions were highly polarized, and five of the remaining nine were not significant or had very low factor loading. These findings required us to think about the measurements of this construct. Indeed, previous studies found permissive style the least reliable of the three and the one with the fewest items

Tabela 3. Correlations among PSDQ, Parental Bonding Index, and Parental Monitoring Scale

\begin{tabular}{|c|c|c|c|c|c|c|}
\hline & $\begin{array}{c}\text { Parental } \\
\text { knowledge }\end{array}$ & $\begin{array}{c}\text { Youth } \\
\text { disclosure }\end{array}$ & $\begin{array}{c}\text { Parental } \\
\text { control }\end{array}$ & $\begin{array}{c}\text { Parental } \\
\text { solicitation }\end{array}$ & Parental care & $\begin{array}{c}\text { Parental } \\
\text { overprotection }\end{array}$ \\
\hline Authoritative & $\begin{array}{l}.39 * * / \\
.47 * *\end{array}$ & $\begin{array}{l}.41 * * / \\
.51 * *\end{array}$ & $\begin{array}{l}.13 * * / \\
.14 * *\end{array}$ & $\begin{array}{l}.43 * * / \\
.43 * *\end{array}$ & $\begin{array}{l}.75 * * / \\
.68 * *\end{array}$ & $\begin{array}{l}-.18 * * / \\
-.25 * *\end{array}$ \\
\hline Authoritarian & $\begin{array}{l}-.21 * * / \\
-.24 * *\end{array}$ & $\begin{array}{l}-.16 * * / \\
-.25 * *\end{array}$ & $\begin{array}{c}-.01 / \\
.04\end{array}$ & $\begin{array}{l}-.16 * * / \\
-.20 * *\end{array}$ & $\begin{array}{l}-.46 * * / \\
-.48 * *\end{array}$ & $\begin{array}{c}.30 * * / \\
.34 * *\end{array}$ \\
\hline Permissive & $\begin{array}{l}-.23 * * / \\
-.27 * *\end{array}$ & $\begin{array}{l}-.10 * / \\
-.16 * *\end{array}$ & $\begin{array}{l}-.12 * * / \\
-.13 * *\end{array}$ & $\begin{array}{c}-.07 / \\
-.14 * *\end{array}$ & $\begin{array}{l}-.16 * * / \\
-.21 * *\end{array}$ & $\begin{array}{l}.16^{* *} / \\
.14^{* *}\end{array}$ \\
\hline
\end{tabular}

Note. Bold numbers indicate the findings of the mother's version

$* p<0.05 ; * * p<0.01$ 
(Alizadeh, Applequist, \& Coolidge, 2007; Coplan, Findlay, \& Nelson, 2004; Daglar, Melhuish, \& Barnes, 2011; Haycraft \& Blissett, 2010; Latouf \& Dunn, 2010; Olivari et al., 2013; Önder \& Gülay, 2009; Rhucharoenpornpanich et al., 2010; Sharma \& Sandhu, 2006). This is particularly true in countries outside the U.S. and Canada, showing some problems in the cultural adaptation of the instrument. Tests of cross-cultural measurement invariance are needed to identify items mostly influenced by cultural aspects. Regarding permissive style, only four items were in the final version of the scale in the present study. This polarization could indicate a social desirability effect; that is, the adolescents did not represent their parents as permissive. This aspect points out a normative belief that leads adolescents to perceive parenting not only in relation to their parents' actual behaviors, but also in relation to the child's perception of how parents should act (Confalonieri et al., 2010). Another possible interpretation is that permissive style is not so frequent among Italian parents. Further studies are needed to better analyze this finding. Moreover, the construct should be better defined and operationalized.

The 40-item scale proved to be invariant regarding factor loadings in the fathers' version, but not in the mothers' version. This means that the measurement of maternal styles differs among adolescents. A deeper investigation of the content of non-invariant items reveals that northern adolescents took into account more warm and reasoning aspects of authoritative maternal style, while southern ones emphasized democratic participation aspects. Regarding the authoritarian style, northern adolescents highlighted corporal punishment more than their southern peers.

Differences between the fathers' and the mothers' versions have been found about testing the invariance of correlations among the three parenting styles. In the fathers' version, authoritative and authoritarian styles were highly and negatively correlated for adolescents in the North, whereas the correlation was low in the South though still negative. In contrast, there was a high positive correlation between the authoritarian and the permissive styles in the South and low positive correlation in the North. These findings emphasize that Northern adolescents think of the authoritative style of fathers as the opposite of the authoritarian style, whereas the South perceives the authoritarian and permissive styles as positively associated. This result supports the hypothesis of Confalonieri et al. (2010) that the fathers' role is perceived as having characteristics of both authoritarian and permissive styles in the south. According to that hypothesis, in southern Italian culture, adolescents' perception of fatherhood is best represented as authoritarian. At the same time, in actual daily interactions, those adolescents enjoy relative autonomy and perform most of the activities outside of family control within a permissive family climate.

No differences were found in correlations among the three parenting styles between the northern and the southern samples in the mothers' version. However, contrary to what was found in the fathers' version, authoritative and permissive styles were significantly and negatively related, even though the correlations were low.

Analyses showed that authoritative and authoritarian styles present coherent correlations with other parent-child relationship quality measures (i.e., parental knowledge, youth disclosure, parental solicitation, parental care and overprotection). On the contrary, permissive style was less well-correlated with similar parent-child measures, showing a weakness in the measurement of that style.

Overall, the findings demonstrate that the 40 -item instrument has acceptable psychometric properties in both versions including acceptable convergent validity. It can be used in the Italian context to measure parenting styles as well. The importance of the present paper is that it is shorter and more stable version of the scale, at least for the adolescents who rated their parents in this study. Indeed, CFA and multigroup CFA showed the strengths and weaknesses of the full-version scale instrument. However, a lot of work remains to be done. First, a statistical comparison of the fathers' and mothers' version of the scale is still needed (Tagliabue \& Lanz, 2011, submitted). Moreover, a crosscultural comparison of this Italian version with the same scale in different cultural contexts is needed to understand if the new structure is usable in a different context. Finally, the present research only collected adolescents' perceptions; thus future research should analyze the parents' perceptions, too.

\section{References}

Alizadeh, H., Applequist, K. F., \& Coolidge, F. L. (2007). Parental self-confidence, parenting styles, and corporal punishment in families of ADHD children in Iran. Child abuse \& neglect, 31, 567-572.

Arbuckle, J. L., \& Wottke, W. (2003). Amos 5.0 update to the user's guide. Chicago: Small Waters Corporation.

Bagozzi, R. P. (1994). Structural equation models in marketing research: Basic principles. In R. P. Bagozzi (Ed.), Basic principles of marketing research (pp. 317-385). Oxford, England: Blackwell.

Baumrind, D. (1971). Current patterns of parental authority. Developmental Psychology Monographs, 4, 1-103.

Baumrind, D. (1989). Rearing competent children. In W. Damon (Ed.), Child development today and tomorrow (pp. 349-378). San Francisco: Jossey-Bass.

Baumrind, D. (1991). Parenting styles and adolescent development. In J. Brooks-Gunn, R. Lerner \& A. C. Peterson (Eds.), The encyclopedia of adolescence (pp. 746-758). New York: Garland.

Bentler, P. M. (1990). Comparative fit indexes in structural models. Psychological Bulletin, 107, 238-246.

Byrne, B. M. (2010). Structural equation modeling with Amos: Basic concepts, applications, and programming (2nd ed.). New York: Taylor and Francis Group.

Chipman, S., Olsen, S. F., Klein, S., Hart, C. H., \& Robinson, C. C. (2000). Differences in retrospective perceptions of parenting of male and female inmates and non-inmates. Family Relations, 49, 5-11.

Confalonieri, E., Bacchini, D., Olivari, M. G., Affuso, G., Tagliabue, S., \& Miranda, M. C. (2010). Adolescenti e stili educativi genitoriali: Quale percezione? Psicologia dell'educazione, 4, 9-27. 
Coplan, R. J., Findlay, L. C., \& Nelson, L. J. (2004). Characteristics of preschoolers with lower perceived competence. Journal of Abnormal Child Psychology, 32, 399-408.

Daglar, M., Melhuish, E. C., \& Barnes, J. (2011). Parenting and preschool child behaviour amongst Turkish immigrant, migrant and non-migrant families. European Journal of Developmental Psychology, 8, 261-279.

Darling, N., \& Steinberg, L. (1993). Parenting style as context: An integrative model. Psychological Bulletin, 113, 487-496.

Haycraft, E., \& Blissett, J. (2010). Eating disorder symptoms and parenting styles. Appetite, 54, 221-224.

Hu, L. T., \& Bentler, P. M. (1999). Cutoff criteria for fit Indexes in covariance structure analysis: Conventional criteria versus new alternatives. Structural Equation Modeling, 6, 1-55.

ISTAT. (2006). Strutture familiari e opinioni su famiglia e figli. Indagine Multiscopo "Famiglia, soggetti sociali e condizione dell'infanzia”. Anno 2003, Roma: Istituto nazionale di statistica.

ISTAT (2013). Lavoro e conciliazione dei tempi di vita. In Istat. Rapporto Bes 2013. Retrieved from http://www.istat.it/it/ files/2013/03/3_lavoro-conciliazione.pdf

Kawabata, Y., Alink, L. R., Tseng, W. L., van IJzendoorn, M. H., \& Crick, N. R. (2011). Maternal and paternal parenting styles associated with relational aggression in children and adolescents: A conceptual analysis and meta-analytic review. Developmental Review, 31, 240-278.

Latouf, N., \& Dunn, M. (2010). Parenting style affecting the social behaviour of five-year-olds. Journal of Psychology in Africa, 20, 109-112.

Maccoby, E. E., \& Martin, J. A. (1983). Socialization in the context of the family: Parent-child interaction. In P. H. Mussen \& E. M. Hetherington (Eds.), Handbook of child psychology, V. 4. Socialization, personality, and social development (pp. 1-102), New York: Wiley.

Miranda, M. C., Bacchini, D., \& Affuso, G. (2012). Validazione di uno strumento per la misura del parental monitoring in un campione di adolescenti italiani. Journal of Developmental Psychology, 101, 32-47.

Newman, K., Harrison, L., Dashiff, C., \& Davies, S. (2008). Relationships between parenting styles and risk behaviors in adolescent health: An integrative literature review. Revista Latino-Americana de Enfermagem, 16, 142-150.

O'Brien, H. (2010). The intergenerational transmission of parenting styles of Irish immigrant mothers. Journal of Family Social Work, 13, 395-409.

Olivari, M. G., Tagliabue, S., \& Confalonieri, E. (2013). Parenting Style and Dimensions Questionnaire: A review of Reliability and Validity. Marriage \& Family Review, 49, 465-490.

Önder, A., \& Gülay, H. (2009). Reliability and validity of parenting styles \& dimensions questionnaire. Procedia - Social and Behavioral Sciences, 1, 508-514.

Parker, G., Tupling, H., \& Brown, L. B. (1979). A parental bonding instrument. British Journal of Medical Psychology, 52, 1-10.

Perlmutter, B. F,. Touliatos, J., \&. Holden G. W (Eds.). (2001). Handbook of family measurement techniques: Vol. 3. Instruments \& index. Thousand Oaks, CA: Sage.

Piko, B. F., \& Balázs, M. Á. (2012). Authoritative parenting style and adolescent smoking and drinking. Addictive Behaviors, $37,353-356$.
Rhucharoenpornpanich, O., Chamratrithirong, A., Fongkaew, W., Rosati, M., Miller, B. A., \& Cupp, P. K. (2010). Parenting and adolescent problem behaviors: A comparative study of sons and daughters in Thailand. Journal of The Medical Association of Thailand, 93, 293-300.

Robinson, C. C., Mandleco, B., Olsen, S. F., \& Hart, C. H. (1995). Authoritative, authoritarian, and permissive parenting practices: Development of a new measure. Psychological Reports, 77, 819-839.

Robinson, C. C., Mandleco, B., Olsen, S. F., \& Hart, C. H. (2001). The parenting styles and dimensions questionnaire. In B. F. Perlmutter, J. Touliatos, \& G. W. Holden (Eds.), Handbook of family measurement techniques: Vol. 3. Instruments \& index (pp. 319-321). Thousand Oaks, CA: Sage.

Scinto, A., Marinangeli, M. G., Kalyvoka, A., Daneluzzo, E., \& Rossi, A. (1999). The use of the Italian version of the Parental Bonding Instrument (PBI) in a clinical sample and in a student group: An exploratory and confirmatory factor analysis study. Epidemiologia e Psichiatria Sociale, 8, 276-283.

Sharma, V., \& Sandhu, G. (2006). A community study of association between parenting dimensions and externalizing behaviors. Journal of Indian Association of Child and Adolescent Mental Health, 2, 48-58.

Stattin, H., \& Kerr, M. (2000). Parental monitoring: A reinterpretation. Child Development, 71, 1072-1085.

Tagliabue, S., \& Lanz, M. (2011, August-September). Measurement invariance assessment within and between interpersonal relationships: The issue of non-independence. Paper presented at the 11th European Conference on Psychological Assessment, Riga, Latvia.

Tagliabue, S., \& Lanz, M. (submitted). Doing research on social and personal relationships: the issue of measurement invariance of non-independent observations. Manuscript submitted for publication.

Tagliabue, S., Olivari, M. G., Miranda, M. C., Affuso, G., Bacchini, D., \& Confalonieri, E., (submitted) Parenting Styles Memories and Communicative Processes in Adolescence.

Touliatos, J., Perlmutter, B. F., Strauss, M. A., \& Holden, G. W. (Eds). (2001). Handbook of Family measurement techniques, V. 2, Thousand Oaks, CA: Sage.

Weber, L., Salvador, A. P., \& Brandenburg, O. (2006). Medindo e promovendo a qualidade na interação familiar. Sobre comportamento e cognição: expondo a variabilidade, 18, 25-40.

Weber, L. N. D., Salvador, A. P. V., \& Brandenburg, O. J. (2009). Escalas de qualidade na interação familiar. In L. Weber \& M. A. Dessen (Eds.), Pesquisando a família. Instrumento para coleta e análise de dados (pp. 57-68). Curitiba: Juruá.

Recebido em 24.01.2013

Primeira decisão editorial em 28.11.2013

Versão final em 13.02.2014

Aceito em 19.02.2014 
Appendix

Italian 40-Item Version

\begin{tabular}{|c|c|}
\hline Item & Italian version \\
\hline 1 & I miei genitori mi incoraggiavano a parlare dei miei problemi \\
\hline 2 & I miei genitori mi educavano più punendomi che ragionando con me \\
\hline 6 & Quando disobbedivo i miei genitori mi sculacciavano \\
\hline 7 & I miei genitori scherzavano e giocavano con me \\
\hline 9 & Quando ero triste o frustrato i miei genitori erano comprensivi e sensibili \\
\hline 10 & I miei genitori mi punivano privandomi di qualcosa, dandomi poche o nessuna spiegazione \\
\hline 12 & Quando ero turbato i miei genitori mi davano conforto e comprensione \\
\hline 13 & Quando mi comportavo male i miei genitori urlavano \\
\hline 14 & I miei genitori erano rilassati e sereni con me \\
\hline 18 & I miei genitori avevano pazienza con me \\
\hline 20 & I miei genitori stabilivano delle punizioni per me, che in realtà non applicavano \\
\hline 21 & I miei genitori erano sensibili ai miei sentimenti e ai miei bisogni \\
\hline 22 & I miei genitori mi permettevano di "dire la mia" sulle regole della famiglia \\
\hline 25 & I miei genitori mi dicevano i motivi per cui le regole dovevano essere rispettate \\
\hline 26 & I miei genitori sembravano preoccuparsi più dei loro sentimenti che dei miei \\
\hline 27 & I miei genitori mi dicevano che apprezzavano quello che cercavo o mi sforzavo di fare \\
\hline 28 & I miei genitori mi punivano mettendomi in castigo con poche o nessuna spiegazione \\
\hline 29 & I miei genitori mi aiutavano a riflettere sulle conseguenze delle mie azioni, invitandomi a parlarne \\
\hline 31 & I miei genitori tenevano in considerazione i miei desideri prima di chiedermi di fare qualcosa \\
\hline 32 & I miei genitori avevano scoppi di rabbia contro di me \\
\hline 33 & I miei genitori sapevano quello che facevo a scuola \\
\hline 34 & I miei genitori mi minacciavano con punizioni più spesso di quanto realmente ne attuassero \\
\hline 35 & I miei genitori mi esprimevano affetto abbracciandomi, baciandomi e tenendomi in braccio \\
\hline 37 & I miei genitori utilizzavano punizioni fisiche per educarmi \\
\hline 39 & I miei genitori si scusavano con me quando erano loro a sbagliare \\
\hline 41 & I miei genitori cedevano nei miei confronti quando mi ribellavo per qualcosa \\
\hline 42 & I miei genitori parlavano e ragionavano con me quando mi comportavo male \\
\hline 43 & I miei genitori mi davano uno schiaffo quando mi comportavo male \\
\hline 44 & I miei genitori erano spesso in disaccordo con me \\
\hline 46 & I miei genitori avevano dimostrazioni di affetto nei miei confronti \\
\hline 48 & I miei genitori mi incoraggiavano a esprimermi liberamente quando ero in disaccordo con loro \\
\hline 51 & I miei genitori mostravano rispetto per le mie opinioni incoraggiandomi ad esprimerle \\
\hline 53 & I miei genitori mi spiegavano che cosa provavano, sia quando mi comportavo bene, sia quando mi comportavo male \\
\hline 54 & I miei genitori utilizzavano le minacce come punizione, con poche o nessuna spiegazione \\
\hline 55 & I miei genitori tenevano in considerazione le mie preferenze quando c'era da prendere una decisione in famiglia \\
\hline 56 & $\begin{array}{l}\text { I miei genitori, quando chiedevo loro il perché di una regola, mi dicevano: - Perché ho detto così, perché sono tuo madre/ } \\
\text { madre e voglio che sia così- }\end{array}$ \\
\hline 57 & I miei genitori apparivano insicuri su come dovevano fare per correggere i miei comportamenti sbagliati \\
\hline 58 & I miei genitori mi spiegavano le conseguenze del mio comportamento \\
\hline 61 & I miei genitori mi strattonavano quando ero disobbediente \\
\hline 62 & I miei genitori davano importanza ai motivi per cui dovevo rispettare le regole \\
\hline
\end{tabular}

